\title{
Spectroscopic Studies on the Interaction of Au(III) with Nucleosides, Nucleotides, and Dimethyl Phosphate
}

\author{
D. CHATTERJI and U. S. NANDI, Department of Inorganic and \\ Physical Chemistry; and S. K. PODDER, Department of Biochemistry, \\ Indian Institute of Science, Bangalore-560012, India
}

\begin{abstract}
Synopsis
A series of complexes of $\mathrm{Au}(\mathrm{III})$ with nucleosides and nucleotides and their methyl derivatives in different stoichiometry have been prepared. Ultraviolet, visible, ir, and nmr studies have been performed to determine the site of binding of these ligands with the metal ion. In (1:4) $\mathrm{Au}(\mathrm{III})$ : guanosine complex, $\mathrm{N}_{7}$ is the binding site, whereas at $1: 1$ complex, a bidentate type of chelation through $\mathrm{C}_{6} \mathrm{O}$ and $\mathrm{N}_{7}$ is observed. $\mathrm{C}_{6}-\mathrm{NH}_{2}$ is favored over $\mathrm{N}_{1}$ as coordinating site at all stoichiometry in the adenosine complex. Inosine binds through $\mathrm{N}_{1}$ at $r=1$. In cytidine, $\mathrm{N}_{1}$ is the binding site, whereas thymidine reacts only at high $\mathrm{pH}$. In the case of nucleotides a bidentate type of chelation through the phosphate and the ring nitrogen occurs. The phosphate binding ability of $\mathrm{Au}$ (III) was further confirmed by studying the interaction of Au(III) with dimethyl phosphate-a conformational analog of the phosphate backbone in DNA chain.
\end{abstract}

\section{INTRODUCTION}

Metal ions are known to bind with nucleic acids and thereby alter their conformation and biological function. ${ }^{1}$ Various studies in the past ${ }^{2,3}$ have shown that alkali and alkaline earth metal ions interact only with the phosphate moiety while the transitional metal ions interact with both the phosphate and bases of nucleic acids. The metal ion-base interaction depends on the nature of both metal and bases; a certain site of coordination is preferred. This base-specific interaction has, therefore, been exploited recently for the sequencing of DNA by electron microscopy, when DNA is labelled with heavy metal ions like Au and Pt.4 This, together with the recent finding that certain transitional metal complexes have been found to be potentially useful in cancer chemotherapy, $, 6,7$ created a renewed interest in the study of the interaction of heavy metal ions with DNA or its components, with respect to (a) the site of binding and (b) the structure and stability of the complex.

$\mathrm{Au}(\mathrm{III})$ isoelectronic with $\mathrm{Pt}(\mathrm{II}) \mathrm{ad}^{8}$ system usually forms square planar complexes in solution. Since the square planar geometry of $\mathrm{Pt}(\mathrm{II})$ is important for its action as an anticancer drug, ${ }^{8} \mathrm{Au}$ (III) salts also can be used for the same purpose with the added advantage of decreased toxicity. 
Furthermore, it has recently been shown that Au(III) interacts quite strongly with adenine nucleotides ${ }^{9}$ and $\mathrm{DNA}^{10}$ and binds to both bases and phosphates of DNA. So far nothing has been reported as to how the bases are involved in the binding. This work was motivated by the thought that information on the nature of interaction of $\mathrm{Au}$ (III) with DNA can be obtained by studying the properties of $\mathrm{Au}$ (III) complexed with various ligands like nucleosides, nucleotides, and dimethyl phosphate with the help of uv, ir, and ${ }^{1} \mathrm{H} \mathrm{nmr}$ spectroscopy. It may be emphasized that the phosphate binding ability of $\mathrm{Au}$ (III) can be better examined with dimethyl phosphate anion $\left(\mathrm{CH}_{3} \mathrm{O}\right)_{2} \mathrm{PO}_{2}^{-} .{ }^{11,12}$

\section{EXPERIMENTAL SECTION}

\section{Materials}

Commercially available nucleosides and nucleotides (P-L Biochemicals, Wisconsin) were used without further purification. $\mathrm{HAuCl}_{4}$ crystals (Johnson Matthey Chemicals Ltd., England) were crystallized from doubly distilled water before use, and purity was checked by the molar extinction coefficient value at $313 \mathrm{~nm}$. Solvents $\mathrm{Me}_{2} \mathrm{SO}$ and methanol were dried and distilled immediately before use. Both $\mathrm{nmr}$ spectroscopy and the Fischer reaction suggest that $\mathrm{Me}_{2} \mathrm{SO}$ contains not more than $1 \% \mathrm{H}_{2} \mathrm{O}$. Water used in the study was always doubly distilled. Methyl derivatives of nucleosides were prepared according to standard methods..$^{13-15}$ Dimethyl phosphate has been prepared in the usual way described by Tsuboi et al. ${ }^{11}$ Purity of all ligands was checked by their extinction value in the uv region.

\section{Equipment}

The spectral measurements were made with a Cary 14/Unicam SP-700A spectrophotometer. Infrared spectra were taken in solid phase in dry $\mathrm{KBr}$ pellets using a Karl Zeiss-Jena spectrometer. ${ }^{1} \mathrm{H} \mathrm{nmr}$ measurements were performed with Varian HA-100 and T- 60 spectrometers in both $\mathrm{D}_{2} \mathrm{O}$ and $\mathrm{Me}_{2} \mathrm{SO}-\mathrm{d}_{6}$ solvents using sodium 2,2, dimethyl-2-silapentane-5-sulfonate and $\mathrm{Me}_{4} \mathrm{Si}$ as internal standards, respectively.

\section{Preparation of the Complexes}

Complexes were prepared by following the procedure described by Cattalini and Tobe. ${ }^{16}$ An aqueous solution of $\mathrm{HAuCl}_{4}$ of known concentration $(0.1 M)$ was neutralized carefully to $\mathrm{pH} 6.5-7$ by the gradual addition of solid $\mathrm{Na}_{2} \mathrm{CO}_{3}$. To this a stoichiometric amount of nucleoside or nucleotide was added in the solid form. In the case of purine nucleosides, a red color developed within 5-10 min and the complex was insoluble in $\mathrm{H}_{2} \mathrm{O}$. Purine nucleotide-Au(III) complex also developed a red color which was soluble in $\mathrm{H}_{2} \mathrm{O}$ and subsequently precipitated by adding cold ethanol. 
Complexes of $\mathrm{Au}(\mathrm{III})$ with cytidine and its derivatives formed soluble, orange complexes in $\mathrm{H}_{2} \mathrm{O}$ which were isolated by evaporating the solvent under reduced pressure. An orange solution of Au(III)-5'dCMP was also precipitated by adding cold ethanol. Au(III)-thymidine complex was only detected at high $\mathrm{pH}$. It could not be isolated due to the formation of metallic gold during solvent evaporation. The precipitated complexes were collected by centrifugation, dried in vacuo, and stored over $\mathrm{P}_{2} \mathrm{O}_{5}$. They were dissolved in fresh solvents prior to measurements. The complexes were reprecipitated slowly by ethanol or reevaporated for elemental analysis, performed by Bhabha Atomic Research Centre, Bombay, India.

\section{Determination of the Stoichiometry: Amount of Nucleoside/Tide per Mole of Au(III)}

A known amount of the $\mathrm{Me}_{2} \mathrm{SO}$ or $\mathrm{H}_{2} \mathrm{O}$ solution of complexes (purine nucleosides are soluble in $\mathrm{Me}_{2} \mathrm{SO}$ ) was transferred to $3-5 \mathrm{ml}$ of $0.1 \mathrm{~N} \mathrm{HCl}$ and kept overnight for the complete breakdown of the complexes. The absorption of the solution was then measured in a cell of $1-\mathrm{cm}$ pathlength at two different wavelengths, namely 270 and $313 \mathrm{~nm}$. Since the absorption of nucleic acid components at $313 \mathrm{~nm}$ can be neglected, the amount of $\mathrm{Au}$ (III) was determined from its known extinction value. ${ }^{17}$ The stoichiometric amount of nucleoside or nucleotide was then calculated by using the following two equations:

$$
\begin{gathered}
A_{313}=\epsilon_{313}^{\mathrm{Au}} c_{\mathrm{Au}} \\
A_{270}=\epsilon_{270}^{\mathrm{Au}} c_{\mathrm{Au}}+\epsilon_{270}^{N} c_{N}
\end{gathered}
$$

where $A, \epsilon$, and $c$ are absorbance, molar extinction, and concentration, respectively. $N$ denotes base unit. The extinction values of nucleosides and nucleotides at $\mathrm{pH} 1$ were taken from the literature. ${ }^{13-15,18}$

\section{RESULTS AND DISCUSSION}

\section{Interaction of Au(III) with Nucleosides and Nucleotides}

Analytical data of the complexes and their stoichiometry are reported in Table I. Spectral studies can be broadly classified under three groupings: visible and $\mathrm{uv}$, ir, and ${ }^{1} \mathrm{H} \mathrm{nmr}$.

\section{Visible and Ultraviolet Spectra}

In Figs. 1 and 2 visible spectra of various $\mathrm{Au}(\mathrm{III})$-nucleoside/(tide) complexes in 1:1 $\mathrm{CH}_{3} \mathrm{OH} / \mathrm{Me}_{2} \mathrm{SO}(\mathrm{v} / \mathrm{v})$ mixture and $\mathrm{H}_{2} \mathrm{O}$ are shown. It is seen that a broad band appears far outside the range of charge-transfer bands $(300-330 \mathrm{~nm})$ from ligand to metal ion. In the case of $\mathrm{AuCl}_{4}^{-} \mathrm{a}$ monotonic increase of absorbance was observed and appeared as a tail of highly intense charge-transfer band. The broad band in the visible region 
TABLE I

Analytical Data of the Complexes ${ }^{\mathrm{a}}$

\begin{tabular}{|c|c|c|c|c|c|c|c|}
\hline \multirow[b]{2}{*}{ Compounds } & \multicolumn{2}{|c|}{$\% \mathrm{C}$} & \multicolumn{2}{|c|}{$\% \mathrm{H}$} & \multicolumn{2}{|c|}{$\% \mathrm{~N}$} & \multirow{2}{*}{$\begin{array}{l}\text { Stoichi- } \\
\text { ometry } \\
\mathrm{Au}^{+3}: n\end{array}$} \\
\hline & Calcd. & $\overline{\text { Obsd. }}$ & Calcd. & Obsd. & Calcd. & Obsd. & \\
\hline$\left[\mathrm{Au}(\mathrm{G})_{4}\right] \mathrm{Cl}_{2} \mathrm{OH}$ & 33.85 & 33.78 & 3.74 & 3.7 & 19.74 & 19.64 & $1: 4$ \\
\hline$\left[\mathrm{Au}(\mathrm{G}) \mathrm{Cl}_{2}\right]$ & 22.81 & 21.85 & 2.2 & 2.44 & 12.72 & 12.74 & $1: 1$ \\
\hline$\left[\mathrm{Au}(\mathrm{A})_{3} \mathrm{Cl}\right](\mathrm{OH})_{2}$ & 33.7 & 33.62 & 3.84 & 3.79 & 19.66 & 19.51 & $1: 3$ \\
\hline$\left[\mathrm{Au}^{\prime} \mathrm{dGMP} \mathrm{Cl}_{2}\right] \mathrm{Na}$ & 18.86 & 18.65 & 1.88 & 2.02 & 10.99 & 10.89 & $1: 1$ \\
\hline$\left[\mathrm{Au}^{\prime} \mathrm{dAMP} \mathrm{Cl} \mathrm{Cl}_{2}\right] \mathrm{Na}$ & 19.23 & 19.2 & 1.92 & 1.88 & 11.69 & 11.75 & $1: 1$ \\
\hline$\left[\mathrm{Au} \mathrm{ICl} \mathrm{IC}_{2}\right]$ & 22.42 & 22.39 & 1.87 & 1.82 & 10.46 & 10.38 & $1: 1$ \\
\hline$\left[\mathrm{AuC}_{2} \mathrm{Cl}_{2}\right] \mathrm{OH}$ & 28.07 & 28.1 & 3.51 & 3.42 & 10.91 & 10.95 & $1: 2$ \\
\hline$\left[\mathrm{Au}^{\prime} \mathrm{dCMP} \mathrm{Cl}_{2}\right] \mathrm{Na}$ & 18.05 & 18.01 & 2.0 & 1.98 & 7.02 & 7.00 & $1: 1$ \\
\hline
\end{tabular}

a Nucleoside/nucleotide $=\mathrm{n}, \mathrm{G}=$ guanosine, $\mathrm{A}=$ adenosine, $5^{\prime} \mathrm{dGMP}=2^{\prime}$-deoxy guanosine 5 'monophosphoric acid, $\mathrm{C}=$ cytidine, $5^{\prime}$ dAMP $=2^{\prime}$-deoxy adenosine $5^{\prime}$ monophosphoric acid, $I=$ inosine, and $5^{\prime} \mathrm{dCMP}=2^{\prime}$-deoxy cytidine $5^{\prime}$ 'monophosphoric acid.

could be detected because the charge-transfer band shifted to lower wavelength in nucleoside/(-tide) complexes. This is what one would expect if " $\mathrm{N}$ " atom of ligand coordinated to central metal atom as lone pair of " $N$ " has greater ionization potential than the $\mathrm{Cl}^{-}$ion. ${ }^{17}$

Because of the overlapping of the highly intense charge-transfer band, the assignment of the $d-d$ transition in $A u(I I I)$ complexes was rather difficult. Recently Mason and $\mathrm{Gray}^{19}$ have shown that at $77^{\circ} \mathrm{K}$, the $\mathrm{d}-\mathrm{d}$ transition can be resolved in the cases of $\left(\mathrm{C}_{4} \mathrm{H}_{9}\right)_{4} \mathrm{NAuX}_{4}$ (where $\mathrm{X}=\mathrm{Cl}^{-}$, $\mathrm{Br}^{-}, \mathrm{SCN}^{-}$) complexes. They found $\mathrm{d}-\mathrm{d}$ transitions along with the charge-transfer band and characterized them in the range of $330-600 \mathrm{~nm}$. The least intense band at the longest wavelength $\left(21,000-26,000 \mathrm{~cm}^{-1}\right)$ was assigned to ${ }^{1} \mathrm{~A}_{1 \mathrm{~g}} \rightarrow{ }^{1} \mathrm{~A}_{2 \mathrm{~g}}$, and ${ }^{1} \mathrm{~A}_{1 \mathrm{~g}} \rightarrow{ }^{1} \mathrm{E}_{\mathrm{g}}$. By analogy one could ascribe the broad visible band above $400 \mathrm{~nm}$ (see Figs. 1 and 2) to ${ }^{1} \mathrm{~A}_{1 \mathrm{~g}} \rightarrow{ }^{1} \mathrm{~A}_{2 \mathrm{~g}}$ and ${ }^{1} \mathrm{~A}_{1 \mathrm{~g}}$ $\rightarrow{ }^{1} \mathrm{E}_{\mathrm{g}}$. An attempt to resolve them further at room temperature by varying solvent composition with different dielectric constants was not successful; however, the $\mathrm{d}-\mathrm{d}$ band of $\mathrm{Au}(\mathrm{III})-5^{\prime} \mathrm{dGMP}$ complex at $r=1$ (where $r=$ $\left(\mathrm{Au}^{+3}\right) /$ (nucleoside/(-tide)) in $\mathrm{Me}_{2} \mathrm{SO}$ is much more intense and resolvable than that in $\mathrm{H}_{2} \mathrm{O}$ (see Fig. 1). The derivative plot $(\Delta \epsilon / \Delta \lambda$ vs $\lambda$ ) (Fig. 2) clearly shows two bands whose respective positions and intensity of absorption are indicated in Table II. It is interesting to note that the intensities of the band depend not only on the ratio of Au(III) to nucleic acid bases, but also on the nature of the nucleoside/(-tide). The intensities of $\mathrm{d}-\mathrm{d}$ transitions of the complexes decrease in the following order: (1:1) Au-guanosine < (1:3)Au-adenosine < (1:4)Au-guanosine < (1:1)Au$3^{\prime}$ dGMP $<(1: 1) A u-5^{\prime}$ dAMP. This is presumably due to the fact that a nucleotide can act as a stronger bidentate ligand.

With pyrimidine nucleosides and nucleotides, the shoulder in the visible region could not be isolated, but the extinction values of $\mathrm{Au}$ (III) complexes are higher than that of $\mathrm{AuCl}_{4}^{-}$, and also the extinction value for one complex 


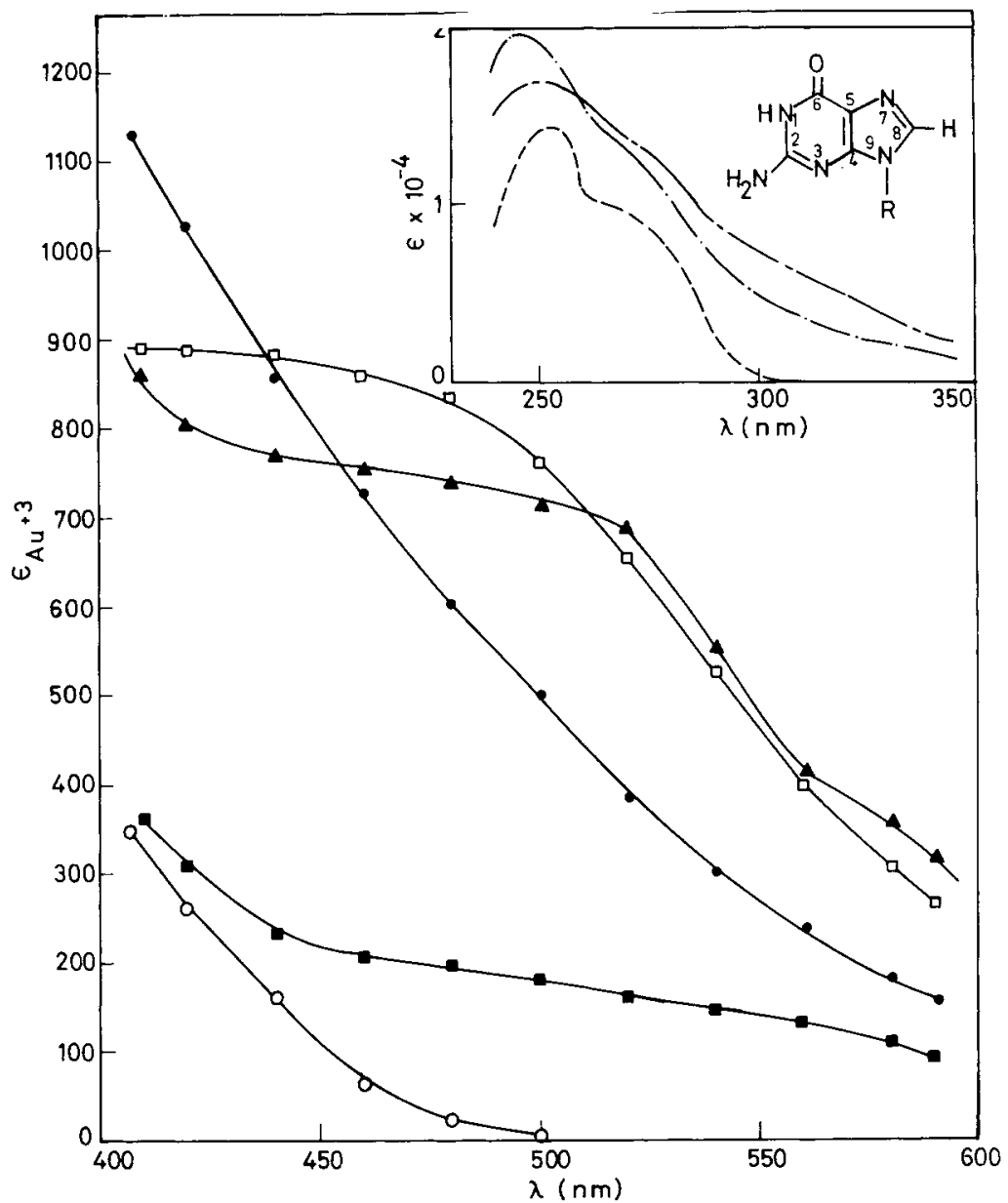

Fig. 1. Visible spectra of $\mathrm{Au}(\mathrm{III})$ complexes in (1:1) $\left.\mathrm{Me}_{2} \mathrm{SO} / \mathrm{methanol}_{\mathrm{V}} / \mathrm{v}\right)$. -O- neutralized Au(III) solution; - - (1:1) Au(III)-guanosine; - - (1:1) Au(III)-5'dGMP in $\mathrm{H}_{2} \mathrm{O}$; - $\mathrm{-}$ - (1:1) Au(III)-5'dGMP; - $\Delta$ - (1:4) Au(III)-guanosine. Inset shows the uv spectra of the complexes along with the structure of guanosine, $R=\beta$-D-ribofuranoside, and for $5^{\prime}$ dGMP, $R=2^{\prime}$ deoxy- $\beta$-D-ribofuranoside 5' -phosphoric acid. - - - 5'dGMP in $\mathrm{H}_{2} \mathrm{O}$; - - - Au(III)-5'dGMP in $\mathrm{H}_{2} \mathrm{O}$; - - $\mathrm{Au}$ (III)-guanosine in $\mathrm{Me}_{2} \mathrm{SO} /$ methanol $(1: 9 \mathrm{v} / \mathrm{v})$.

differs from others, indicating that different types of complexes were formed. In the case of $\mathrm{Au}$ (III)-thymidine complex this change was observed when the $\mathrm{pH}$ of the solution was changed from 6.5 to 8 (not shown).

A prior knowledge of the sites of coordination, however, is necessary to correlate visible band position and structure. The following sections describe ir and ${ }^{1} \mathrm{H} \mathrm{nmr}$ studies carried out to obtain this information.

\section{IR Spectra}

We were mainly concerned with the qualitative change in the ir band in the region $900-1300 \mathrm{~cm}^{-1}$ (phosphate region) and $1500-1800 \mathrm{~cm}^{-1}$ (cor- 


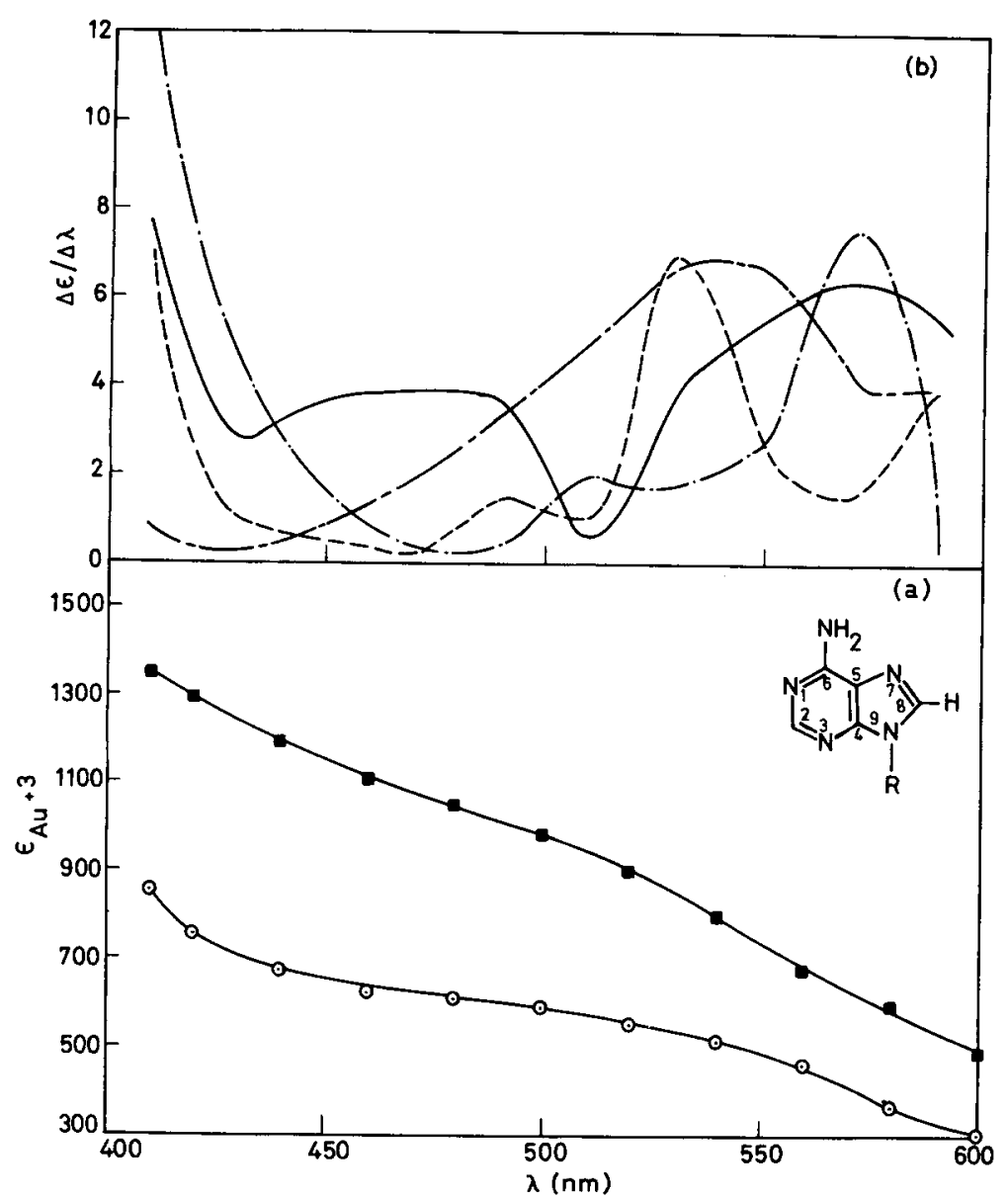

Fig. 2. (a) Visible spectra of $\mathrm{Au}$ (III) complexes in $\mathrm{Me}_{2} \mathrm{SO} /$ methanol (1:1 v/v). - $\odot-(1: 3)$ $\mathrm{Au}(\mathrm{III})$-adenosine; - $-\mathrm{Au}$ (III)-5'dAMP and the structure of adenosine, $\mathrm{R}=\boldsymbol{\beta}$-D-ribofuranoside, and for $5^{\prime} \mathrm{dAMP}, \mathrm{R}=2^{\prime}$ deoxy- $\beta$-D-ribofuranoside $5^{\prime}$-phosphoric acid. (b) Derivative plot of absorption spectra shown in Figs. 1 and 2(a). - (1:1) Au(III)-5'dAMP; -. (1:3) $\mathrm{Au}(\mathrm{III})$-adenosine; - - - (1:1) Au(III)-5'dGMP; - . - (1:4) Au(III)-guanosine.

responding to the in-plane vibrational modes of $\mathrm{C}=\mathrm{O}, \mathrm{C}=\mathrm{C}, \mathrm{C}=\mathrm{N}$, and $\left.\mathrm{NH}_{2}\right)^{20}$ due to the formation of the complex. Hartman ${ }^{21}$ has studied the ir spectra of $\mathrm{AuCl}_{3}$ with nucleosides and nucleotides but no detailed analysis has been given. Tsuboi et al. ${ }^{22}$ elaborately described the characteristic ir spectra of nucleic acid-base residues and assigned the spectra by normal coordination analysis. Change in the spectra of complexes of Au salts is compared here with the assignments of Tsuboi et al. ${ }^{20}$ to find the site of complexation as given in Table III.

Guanosine and its derivatives. Infrared spectra of the complexes of $\mathrm{Au}(\mathrm{III})$ and guanosine $(r=0.25,1), 7$-methyl guanosine $(r=1)$, inosine ( $r$ $=1)$, and 5'dGMP $(r=1)$ have been studied. We were mainly interested in $\mathrm{N}_{1} \mathrm{H}$ stretching and bending frequencies (around 3150 and $1450 \mathrm{~cm}^{-1}$ ), $\mathrm{C}_{6}=\mathrm{O}$, stretching frequency $\left(1690 \mathrm{~cm}^{-1}\right), \mathrm{C}_{2}-\mathrm{NH}_{2}$ scissoring vibration (1640 
TABLE II

Energy of Absorption of the Complexes in $\mathrm{Me}_{2} \mathrm{SO} / \mathrm{Methanol}$

\begin{tabular}{cl}
\hline \multicolumn{1}{c}{ Complex } & \multicolumn{1}{c}{$\begin{array}{c}\text { Energy of Absorption } \\
\left(\mathrm{cm}^{-1}\right)\end{array}$} \\
\hline Au(III)-guanosine(1:4) & $2,088(725), 1,870(610)^{\mathrm{a}}$ \\
Au(III)-5' dGMP(1:1) & $1,850(640)$ \\
Au(III)-guanosine(1:1) & $2,000(190)$ \\
Au(III)-adenosine(1:3) & $1,960(590), 1,754(450)$ \\
$\mathrm{Au}(\mathrm{III})-5^{\prime}$ dAMP(1:1) & $2,130(1100), 1,754(630)$ \\
\hline
\end{tabular}

a Numbers in the parenthesis indicate the extinction values.

$\mathrm{cm}^{-1}$ ), and ring vibration of $\mathrm{C}=\mathrm{C}$ and $\mathrm{C}=\mathrm{N}$ (around $1600 \mathrm{~cm}^{-1}$ ). In the $\mathrm{Au}$ (III) complex of guanosine at $r=0.25$ these above-mentioned bands were not changed except for the decrease in intensity of the $1600 \mathrm{~cm}^{-1}$ band which appeared as a shoulder. Since coordination through nitrogen is expected, the only possible sites of binding are $\mathrm{N}_{3}$ and $\mathrm{N}_{7}$, which would disturb the ring vibration. Due to the basicity, $\mathrm{N}_{7}$ was earlier assumed to be the most potent metal binding site, ${ }^{2}$ which is even true for the gold complex at small $r$ values, later proved by nmr studies. At $r=1$, the 1600 $\mathrm{cm}^{-1}$ band was greatly reduced, as found in the $\mathrm{Au}(\mathrm{III})$-guanosine $(r=0.25)$ complex. The additional change was observed for $\mathrm{C}_{6}=\mathrm{O}$ frequency $(1690$ $\mathrm{cm}^{-1}$ ), which completely disappeared in the complex. In contrast, the 1640 $\mathrm{cm}^{-1}$ band of $\mathrm{C}_{2}-\mathrm{NH}_{2}$ was shifted by $20 \mathrm{~cm}^{-1}$ in the $\mathrm{Au}(\mathrm{III})-7$ methyl guanosine complex $(r=1)$, along with a change of $\mathrm{N}_{1} \mathrm{H}$ group frequency. In both the cases it can be assumed that a bidentate type of bonding has taken place, either through $\mathrm{C}_{6}=\mathrm{O}, \mathrm{N}_{7}$ or through $\mathrm{N}_{1} \mathrm{H}$ and $\mathrm{C}_{2}-\mathrm{NH}_{2}$.

In spite of the basicity at the $N_{7}$ site, inosine binds through $N_{1}$ in (1:1) complex. The changes in spectra are similar to the (1:1) Au(III)-7-methyl inosine complex as given in Table III. In $5^{\prime}$ dGMP complexes of $\mathrm{Au}(\mathrm{III})$ $1230 \mathrm{~cm}^{-1}$ band of $\mathrm{P}=0$ was absent, with the appearance of a small band around $1200 \mathrm{~cm}^{-1}$, which can be attributed to phosphate binding. The changes in ring vibrations were also observed.

Adenosine and its derivatives. Infrared spectra of Au(III)-adenosine at $r=0.25,0.33$, and 1 were found to be identical to each other. The intense band around $1680 \mathrm{~cm}^{-1}$ of adenosine was found to be greatly reduced in all these complexes with no other appreciable change. We have attributed this to the $\mathrm{C}_{6}-\mathrm{NH}_{2}$ coordination in the metal complex. The change in 1680 $\mathrm{cm}^{-1} \mathrm{NH}_{2}$ scissoring vibration was identical to that of $\mathrm{Au}(\mathrm{III})-1$-methyl adenosine complex at $r=1$. On the other hand, ir data show that binding through $\mathrm{N}_{1}$ or $\mathrm{N}_{7}$ and phosphate took place in the (1:1) Au(III)-5'dAMP complex.

Cytidine and its derivatives. The strong bands of cytidine around 1650 $\mathrm{cm}^{-1}\left(\mathrm{C}_{2}=\mathrm{O}\right.$ stretching $)$, and $1670 \mathrm{~cm}^{-1}, 1600 \mathrm{~cm}^{-1}\left(\mathrm{C}_{6}-\mathrm{NH}_{2}\right.$ coupled to ring vibration) did not change appreciably at $r=0.25,0.5$, or 1 , except the reduced intensity of the $1600 \mathrm{~cm}^{-1}$ band showing $\mathrm{Au}^{+3}$ is not coordinated 
TABLE III

Infrared Absorption Bands of the Nucleosides and Nucleotides and their Complexes in Solid Phase in Dry KBr Pellets

\begin{tabular}{|c|c|c|}
\hline Compounds & $\begin{array}{l}\text { IR Bands } \\
\left(\mathrm{cm}^{-1}\right)^{\mathbf{a}}\end{array}$ & Special Remarks \\
\hline Guanosine & $\begin{array}{l}1540(\mathrm{Sh}, \mathrm{ms}), 1600(\mathrm{~b}, \mathrm{~s}) \\
1640(\mathrm{Sh}, \mathrm{s}), 1690(\mathrm{~b}, \mathrm{~s}) \\
3150(\mathrm{~b}, \mathrm{~s})\end{array}$ & $\begin{array}{l}1540 \text { corresponds to } \mathrm{N}_{1} \mathrm{H} \\
\text { lending, } 3150 \ldots \mathrm{N}_{1} \mathrm{H} \\
\text { stretching, } 1600 \ldots \text { ring } \\
\text { vibration due to } \mathrm{C}=\mathrm{C}, \mathrm{C}=\mathrm{N} \text {, } \\
1640 \ldots \mathrm{NH}_{2} \text { vibration, } 1690 \\
\ldots \mathrm{C}=\mathrm{O} \text { stretching }\end{array}$ \\
\hline $\begin{array}{l}\mathrm{Au}(\mathrm{III}) \text {-guanosine } \\
\quad(r=0.25)\end{array}$ & $\begin{array}{l}1540(\mathrm{Sh}, \mathrm{ms}), 1600(\mathrm{~b}, \mathrm{w}) \\
1640(\mathrm{Sh}, \mathrm{s}), 1690(\mathrm{~b}, \mathrm{~s}) \\
3150(\mathrm{~b}, \mathrm{~s})\end{array}$ & Coordination through $\mathrm{N}_{7}$ \\
\hline $\begin{array}{l}\text { Au(III)-guanosine } \\
\quad(r=1)\end{array}$ & $\begin{array}{c}1540(\mathrm{Sh}, \mathrm{ms}), 1600(\mathrm{~b}, \mathrm{w}) \\
1640(\mathrm{Sh}, \mathrm{s}), 3150(\mathrm{~b}, \mathrm{~s})\end{array}$ & $\begin{array}{l}\text { Coordination through } \mathrm{C}_{6}-\mathrm{O} \text { and } \\
\mathrm{N}_{7}\end{array}$ \\
\hline 7 methyl guanosine & $\begin{array}{l}\text { 1540(Sh,ms), } 1590(\mathrm{~b}, \mathrm{~ms}) \\
\text { 1640(Sh,w), } 1690(\mathrm{~b}, \mathrm{~s}) \\
3150(\mathrm{~b}, \mathrm{~s})\end{array}$ & $\begin{array}{l}\text { Assignments are similar to } \\
\text { guanosine, } 1590 \text { corresponds } \\
\text { to } \mathrm{C}=\mathrm{C}, \mathrm{C}=\mathrm{N}\end{array}$ \\
\hline $\begin{array}{l}\text { Au(III)-7 methyl } \\
\text { guanosine }(r=1)\end{array}$ & $\begin{array}{l}1540(\text { shoulder }), 1590(\mathrm{~b}, \mathrm{~ms}) \\
1660(\mathrm{~b}, \mathrm{w}), 1690(\mathrm{~b}, \mathrm{~s})\end{array}$ & $\begin{array}{l}\text { Coordination through } \mathrm{N}_{1} \mathrm{H} \text { and } \\
\mathrm{C}_{2}-\mathrm{NH}_{2}\end{array}$ \\
\hline Inosine & $\begin{array}{l}1540(\mathrm{Sh}, \mathrm{s}), 1610(\mathrm{~b}, \mathrm{~s}), 1690(\mathrm{~b}, \mathrm{~s}) \\
\quad 3150(\mathrm{~b}, \mathrm{~s})\end{array}$ & $\begin{array}{l}1610 \text { corresponds to ring } \mathrm{C}=\mathrm{C} \\
\mathrm{C}=\mathrm{N}, \text { others similar to } \\
\text { guanosine }\end{array}$ \\
\hline $\begin{array}{l}\text { Au(III)-inosine }(r \\
=1)\end{array}$ & $\begin{array}{l}1540(\text { Shoulder }), 1610(\mathrm{~b}, \mathrm{~s}) \\
1690(\mathrm{~b}, \mathrm{~s})\end{array}$ & Coordination through $\mathrm{N}_{1} \mathrm{H}$ \\
\hline 7 methyl inosine & $\begin{array}{l}1540(\mathrm{Sh}, \mathrm{s}), 1600(\mathrm{Sh}, \mathrm{ms}) \\
1700(\mathrm{~b}, \mathrm{~s}), 3150(\mathrm{~b}, \mathrm{~s})\end{array}$ & $\begin{array}{l}1600 \text { corresponds to ring } C=C, \\
C=N, 1700 \ldots C=0 \text {, others } \\
\text { similar to guanosine }\end{array}$ \\
\hline $\begin{array}{l}\text { Au(III)-7 methyl } \\
\text { inosine }(r=1)\end{array}$ & $\begin{array}{l}1540 \text { (Shoulder), } 1600 \text { (Sh,ms), } \\
1700(\mathrm{~b}, \mathrm{~s})\end{array}$ & Coordination through $\mathrm{N}_{1}$ \\
\hline 5'dGMP & $\begin{array}{l}980(\mathrm{Sh}, \mathrm{s}), 1100(\mathrm{~b}, \mathrm{~s}) \\
1190(\mathrm{Sh}, \mathrm{w}), 1230(\mathrm{~b}, \mathrm{~s}) \\
1400(\mathrm{Sh}, \mathrm{ms}), 1540(\mathrm{Sh}, \mathrm{ms}) \\
1610(\mathrm{~b}, \mathrm{~s}), 1660(\mathrm{Sh}, \mathrm{s}) \\
1700(\mathrm{~b}, \mathrm{~s}), 3150(\mathrm{~b}, \mathrm{~s})\end{array}$ & $\begin{array}{l}900-1300 \mathrm{~cm}^{-1} \text { phosphate } \\
\text { region, } 1230 \text { corresponds to } \\
\mathrm{P}=0 \text { stretching, other bands } \\
\text { are same as guanosine }\end{array}$ \\
\hline Au(III)-5'dGMP & $\begin{array}{l}980(\mathrm{w}), 1100(\mathrm{~b}, \mathrm{~s}), 1200(\mathrm{w}, \mathrm{Sh}) \\
1400(\mathrm{Sh}, \mathrm{s}), 1550(\mathrm{Sh}, \mathrm{ms}) \\
1610(\mathrm{Shoulder}), 1660(\mathrm{Sh}, \mathrm{s}) \\
1700(\mathrm{~b}, \mathrm{~s}), 3150(\mathrm{~b}, \mathrm{~s})\end{array}$ & $\begin{array}{l}\text { Coordination through } \\
\text { phosphate and } N_{7}\end{array}$ \\
\hline Adenosine & $1575(\mathrm{Sh}, \mathrm{s}), 1610(\mathrm{~b}, \mathrm{~s}), 1680(\mathrm{~b}, \mathrm{~s})$ & $\begin{array}{l}1610 \text { corresponds to ring } \\
\text { vibration, } 1680 \text { band is due } \\
\text { to } \mathrm{NH}_{2} \text { scissoring }\end{array}$ \\
\hline $\begin{array}{l}\text { Au(III)-adenosine } \\
(r=0.33)\end{array}$ & $\begin{array}{c}\text { 1575(Sh,s), } 1610(\mathrm{~b}, \mathrm{~s}) \\
\text { 1680(Shoulder) }\end{array}$ & Coordination through $\mathrm{C}_{6}-\mathrm{NH}_{2}$ \\
\hline 1-methyl adenosine & $1600(\mathrm{~b}, \mathrm{~ms}), 1690(\mathrm{~b}, \mathrm{~s})$ & $\begin{array}{l}1600 \text { corresponds to ring } \\
\text { vibration, } 1690 \text { band is due } \\
\text { to } \mathrm{NH}_{2} \text { vibration }\end{array}$ \\
\hline $\begin{array}{l}\text { Au(III)-1 methyl } \\
\text { adenosine }(r=1)\end{array}$ & $1600(\mathrm{~b}, \mathrm{~ms}), 1700$ (shoulder) & Coordination through $\mathrm{C}_{6}-\mathrm{NH}_{2}$ \\
\hline $5^{\prime}$ dAMP & $\begin{array}{l}930(\mathrm{Sh}, \mathrm{s}), 980(\mathrm{Sh}, \mathrm{ms}) \\
1100(\mathrm{Sh}, \mathrm{s}), 1220(\mathrm{Sh}, \mathrm{s}) \\
1610(\mathrm{Sh}, \mathrm{s}), 1700(\mathrm{~b}, \mathrm{~s})\end{array}$ & $\begin{array}{l}900-1300 \mathrm{~cm}^{-1} \text { is phosphate } \\
\text { region with } 1220 \mathrm{~cm}^{-1} \text { band } \\
\text { due to } \mathrm{P}=0 \text { stretching, } 1610 \\
\ldots \text { ring vibration, } 1700 \ldots \\
\mathrm{NH}_{2}\end{array}$ \\
\hline
\end{tabular}


TABLE III (continued)

\begin{tabular}{|c|c|c|}
\hline Compounds & $\begin{array}{l}\text { IR Bands } \\
\left(\mathrm{cm}^{-1}\right)^{\mathrm{a}}\end{array}$ & Special Remarks \\
\hline $\begin{array}{l}\text { Au(III) }-5 \text { 'dAMP }(r \\
\quad=1)\end{array}$ & $\begin{array}{c}930(\mathrm{Sh}, \mathrm{s}), 980(\mathrm{Sh}, \mathrm{ms}) \\
1100(\mathrm{w}, \mathrm{s}), 1230(\mathrm{w}, \mathrm{b}) \\
1600(\mathrm{w}, \mathrm{b}), 1700(\mathrm{~b}, \mathrm{~s})\end{array}$ & $\begin{array}{l}\text { Coordination through } \\
\text { phosphate and } N_{1} \text { or } N_{7}\end{array}$ \\
\hline Cytidine & $\begin{array}{c}1530(\mathrm{Sh}, \mathrm{ms}), 1600(\mathrm{~b}, \mathrm{~ms}) \\
1650(\mathrm{Sh}, \mathrm{s}), 1670(\mathrm{~b}, \mathrm{~s})\end{array}$ & $\begin{array}{l}1530 \text { corresponds to ring } \\
\text { vibration, } 1670 \text { and } 1600 \ldots \\
\text { coupled vibration of } \mathrm{C}_{6}-\mathrm{NH}_{2} \\
\text { and ring } \mathrm{C}=\mathrm{C} \text { and } \mathrm{C}=\mathrm{N}\end{array}$ \\
\hline $\begin{array}{l}\text { Au(III)-cytidine }(r \\
\quad=0.5)\end{array}$ & $\begin{array}{l}\text { 1600(shoulder), 1650(Sh,s), } \\
\quad 1670(\mathrm{~b}, \mathrm{~s})\end{array}$ & Coordination through $\mathrm{N}_{1}$ \\
\hline 1-methyl cytidine & $\begin{array}{l}1540(\mathrm{~b}, \mathrm{w}), 1600(\mathrm{~b}, \mathrm{w}), 1670(\mathrm{~b}, \mathrm{~s}) \\
\quad 1640(\mathrm{Sh}, \mathrm{s})\end{array}$ & $\begin{array}{l}1540 \text { corresponds to ring } \\
\text { vibration, } 1670 \text { and } 1600 \ldots \\
\text { coupled vibration of } \mathrm{C}_{6}-\mathrm{NH}_{2} \\
\text { and } \mathrm{C}=\mathrm{C}, \mathrm{C}=\mathrm{N}, 1640 \ldots \\
\mathrm{C}=\mathrm{O} \text { stretching }\end{array}$ \\
\hline $\begin{array}{r}\text { Au(III)-1-methyl } \\
\text { cytidine }(r=1)\end{array}$ & $\begin{array}{l}1540(\mathrm{~b}, \mathrm{w}), 1600(\mathrm{~b}, \mathrm{w}) \\
1640(\mathrm{Sh}, \mathrm{s}), 1700(\mathrm{~b}, \mathrm{w})\end{array}$ & Coordination through $\mathrm{C}_{6}-\mathrm{NH}_{2}$ \\
\hline 5 'dCMP & $\begin{array}{l}960(\mathrm{Sh}, \mathrm{s}), 1100(\mathrm{Sh}, \mathrm{s}) \\
1230(\mathrm{Sh}, \mathrm{s}), 1540(\mathrm{Sh}, \mathrm{ms}) \\
1600(\mathrm{~b}, \mathrm{~ms}), 1650(\mathrm{Sh}, \mathrm{s}) \\
1670(\mathrm{~b}, \mathrm{~s})\end{array}$ & $\begin{array}{l}\text { Assignments are same as other } \\
\text { nucleotides and cytidine }\end{array}$ \\
\hline $\begin{array}{l}\mathrm{Au}(\mathrm{III})-5 \text { dCMP }(r \\
\quad=1)\end{array}$ & $\begin{array}{l}950(\mathrm{Sh}, \mathrm{s}), 1100(\mathrm{~b}, \mathrm{w}) \\
1220(\mathrm{sh} \text { ) } \\
1650(\mathrm{Sh}, \mathrm{s}), 1670(\mathrm{~b}, \mathrm{~s})\end{array}$ & $\begin{array}{l}\text { Coordination through } N_{1} \text { and } \\
\text { phosphate }\end{array}$ \\
\hline
\end{tabular}

a $\mathrm{S}=$ strong, $\mathrm{Sh}=$ sharp, $\mathrm{ms}=$ medium strong, $\mathrm{w}=$ weak, $\mathrm{b}=$ broad.

to any of these groups. The band of the ligand around $1530 \mathrm{~cm}^{-1}$ disappeared in the complex. This can be attributed to coordination through $\mathrm{N}_{1}$. In (1:1) 1-methyl cytidine-Au(III) complex, the band around 1670 $\mathrm{cm}^{-1}$ disappeared and the $1600 \mathrm{~cm}^{-1}$ band was further reduced, indicating in this case that $\mathrm{C}_{6}-\mathrm{NH}_{2}$ takes part in binding to metal.

\section{${ }^{1}$ H NMR Studies}

Due to the limited solubilities of several complexes in $\mathrm{Me}_{2} \mathrm{SO}$, the $\mathrm{nmr}$ spectra were only analyzed for Au(III)-guanosine $(r=0.25,1), \mathrm{Au}(\mathrm{III})$ $5^{\prime}$ dGMP $(r=1)$, Au(III)-adenosine $(r=0.33)$, Au(III)-5'dAMP $(r=1)$, $\mathrm{Au}(\mathrm{III})$-cytidine $(r=0.5)$, and Au(III)-5'dCMP $(r=1)$ compounds. Changes in resonance positions were also noted in the original solution of $\mathrm{Au}$ (III) with thymidine (stoichiometry maintained as 1:1) at $\mathrm{pH}$. The assignments of the $\mathrm{nmr}$ lines given in the figures were established previously. ${ }^{23-25}$

Guanosine and $5^{\prime} d G M P$ complexes. Figure 3 shows the change in $\mathrm{nmr}$ spectra of guanosine in the Au-complex at different stoichiometries. The peaks due to the sugar portion of nucleoside did not change appreciably and are not reported here. This is what one would expect, since the sugar ring is not participating in coordination. In $r=0.25 \mathrm{Au}(\mathrm{III})$-guanosine, 


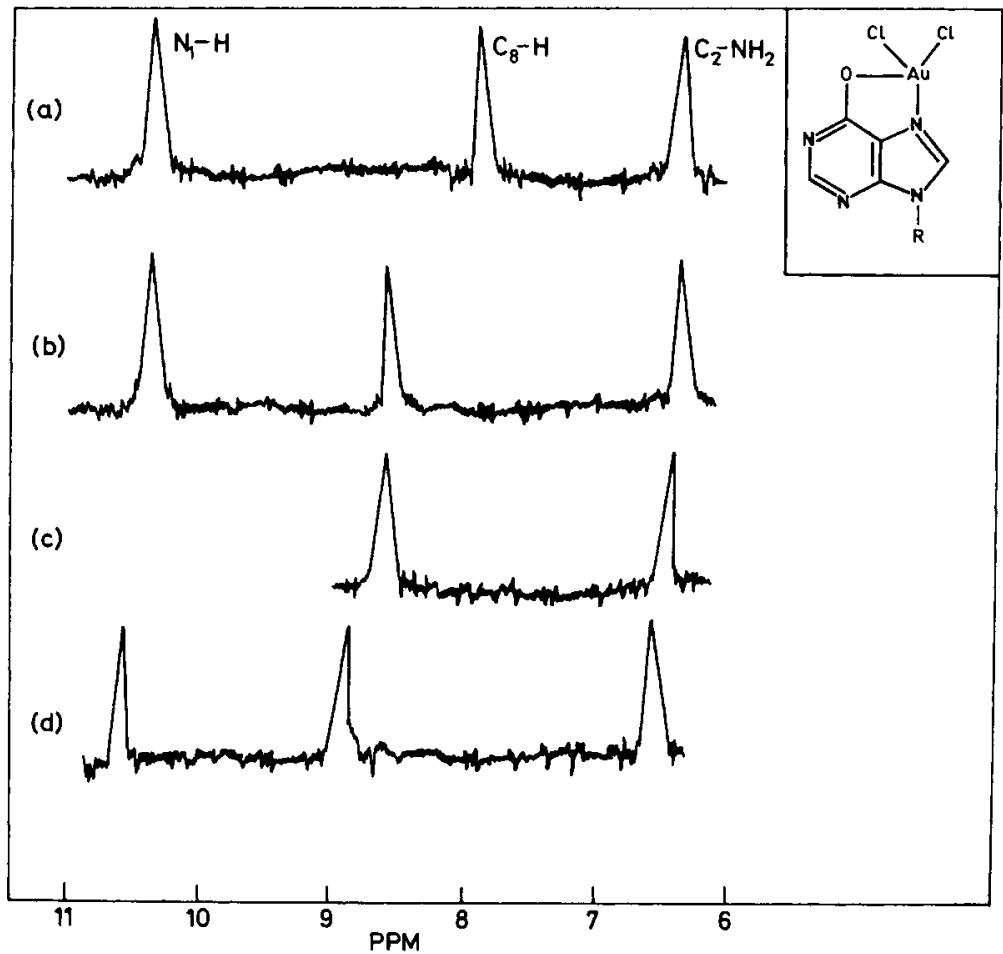

Fig. 3. ${ }^{1} \mathrm{H} \mathrm{nmr}$ spectra of nucleosides, Au(III)-nucleoside, and Au(III)-nucleotide complexes in $\mathrm{Me}_{2} \mathrm{SO}-\mathrm{d}_{6}$ using $\mathrm{Me}_{4} \mathrm{Si}$ as an internal standard. (a) Guanosine, (b) Au(III)-guanosine ( $r$ $=0.25)$, (c) Au(III)-guanosine ( $r=1$ ), (d) Au(III)-5'dGMP ( $r=1)$. Inset shows the structure of Au(III)-guanosine ( $r=1)$.

$\mathrm{C}_{8}-\mathrm{H}$ is shifted downfield without much change in other peak positions. This clearly indicates $\mathrm{N}_{7}$ is the site for coordination and consistent with ir data. The donation of a lone pair of electrons from $\mathrm{N}_{7}$ has its effect only on neighboring $\mathrm{C}_{8}$, and as the $\mathrm{N}_{1} \mathrm{H}$ and $\mathrm{C}_{2}-\mathrm{NH}_{2}$ are far away from $\mathrm{N}_{7}$, no effect was produced. In a similar way, the $\mathrm{C}_{8}-\mathrm{H}$ peak was also shifted downfield in the 1:1 $\mathrm{Au}(\mathrm{III})$-guanosine complex and the $\mathrm{C}_{2}-\mathrm{NH}_{2}$ peak did not change at all. However, the absorption due to $\mathrm{N}_{1} \mathrm{H}$ could not be detected downfield or at higher amplitude. These results are consistent with ir data. If we assume that a covalent and coordination type of bonding were present in the $1: 1$ complex through $\mathrm{C}_{6}-\mathrm{O}$ and $\mathrm{N}_{7}$, respectively, the absence of $\mathrm{N}_{1} \mathrm{H}$ peak in $\mathrm{nmr}$ could be explained. At $\mathrm{pH} 6.5 \mathrm{AuCl}_{4}^{-}$exists as $\mathrm{AuCl}_{2}(\mathrm{OH})_{2}^{-}$and forms square planar complexes. So a bidentate type of chelation through $\mathrm{N}_{7}$ and $\mathrm{C}_{6}-\mathrm{O}$ can take place by the liberation of $20 \mathrm{H}^{-}$ groups from $\mathrm{AuCl}_{2}(\mathrm{OH})_{2}^{-}$, similar to $\mathrm{Pt}(\mathrm{II})$ complexes. ${ }^{8}$ The absence of the $\mathrm{N}_{1} \mathrm{H}$ peak confirms the proton removal due to complexation, but for simultaneous $\mathrm{OH}^{-}$liberation no quantitative $\mathrm{pH}$-titration studies could be performed. The inset in Fig. 3 shows the possible structure for the 1:1 $\mathrm{Au}(\mathrm{III})$-guanosine complex. $\mathrm{N}_{7}$ coordination in metal binding is well 


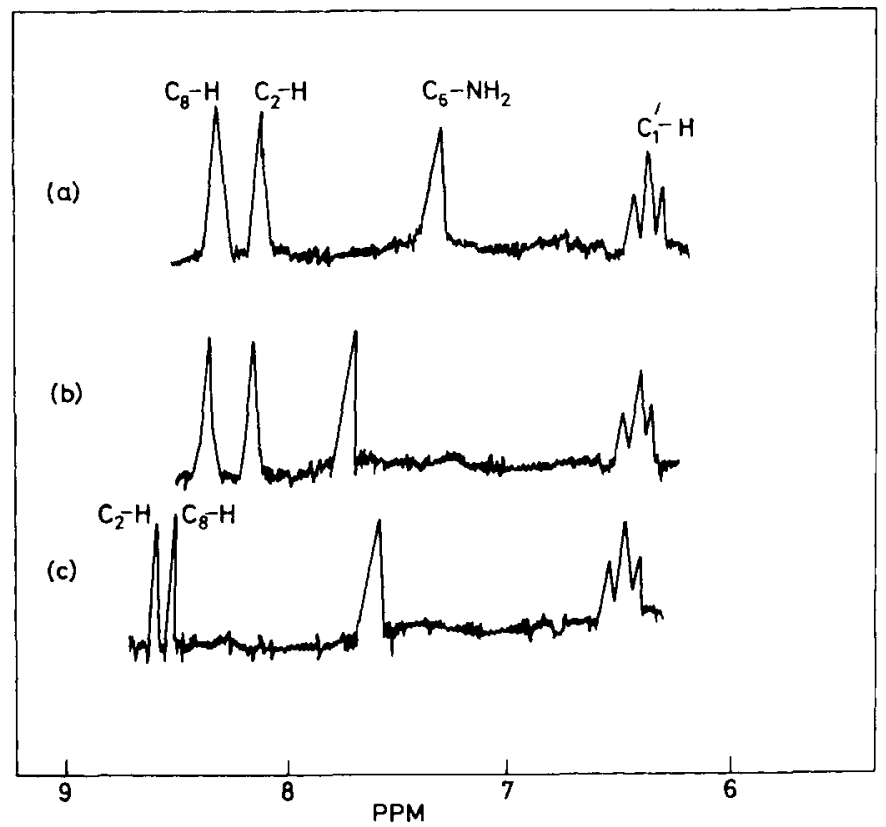

Fig. 4. ${ }^{1} \mathrm{H}$ nmr spectra of nucleosides, $\mathrm{Au}(\mathrm{III})$-nucleoside, and $\mathrm{Au}$ (III)-nucleotide complexes in $\mathrm{Me}_{2} \mathrm{SO}-\mathrm{d}_{6}$ using $\mathrm{Me}_{4} \mathrm{Si}$ as an internal standard. (a) Adenosine, (b) Au(III)-adenosine ( $r$ $=0.33$ ), (c) Au(III)-5'dAMP $(r=1)$.

documented in the literature, including a recent study ${ }^{26}$ on $\mathrm{Pt}(\mathrm{II})$-guanosine and -ionisine complexes where the guanosine was assumed to be a poor bidentate ligand. But our spectral results and analytical data show the above assumption is not true, and this kind of stoichiometry dependent different type of chelation is unique for guanosine. In the case of 5 -dGMP complex (cf. Fig. 3) $\mathrm{C}_{8}-\mathrm{H}$ was again shifted downfield without any other change, indicating that $\mathrm{N}_{7}$ is the preferable site for binding.

Adenosine and 5'dAMP complexes. In the complex of $\mathrm{Au}$ (III)-adenosine, $\mathrm{C}_{6}-\mathrm{NH}_{2}$ was shifted by $50 \mathrm{~Hz}$ (Fig. 4) downfield with no other change which can be attributed to the participation of a lone pair of electrons of the amino group in Au(III) chelation. This is in agreement with our ir data. The nmr spectra of nucleotides are not given in the figures. The only change in the nmr spectra one can observe between purine nucleoside and nucleotide is the downfield shift of $\mathrm{C}_{8}-\mathrm{H}$ by $0.2 \delta$. In the $1: 1$ complex of $\mathrm{Au}(\mathrm{III})-5^{\prime} \mathrm{dAMP}$, this $\mathrm{C}_{8}-\mathrm{H}$ peak around $8.5 \delta$ did not change its position significantly, whereas $\mathrm{C}_{2} \mathrm{H}$ and $\mathrm{C}_{6}-\mathrm{NH}_{2}$ shifted downfield, showing that $\mathrm{N}_{1}$ is the site for coordination (cf. Fig. 4). If the coordination had taken place through $\mathrm{N}_{7}$, the peaks due to $\mathrm{C}_{2}-\mathrm{H}$ and $\mathrm{C}_{6}-\mathrm{NH}_{2}$ need not be shifted. This indicates our assignments are correct. Adenosine has been reported to bind to different metal ions through both $\mathrm{C}_{6}-\mathrm{NH}_{2}$ and $\mathrm{N}_{7} \cdot{ }^{27-29}$ Our results show that for $\mathrm{Au}(\mathrm{III})$-adenosine complex at all $r$ values, $\mathrm{C}_{6}-\mathrm{NH}_{2}$ is the only binding site. 
Cytidine and thymidine complexes. The nmr spectra of cytidine in $\mathrm{D}_{2} \mathrm{O}$ have previously been assigned. ${ }^{25}$ The $\mathrm{H}_{4}$ is a downfield doublet and $\mathrm{H}_{5}$ an upfield doublet close to the doublet of $\mathrm{H}_{1}^{\prime}$. On complexation the $\mathrm{H}_{5}$ doublet shifted downfield, indicating it was close to the metal binding site (Fig. 5). Similar results were observed with 5 dCMP at $r=1$. These

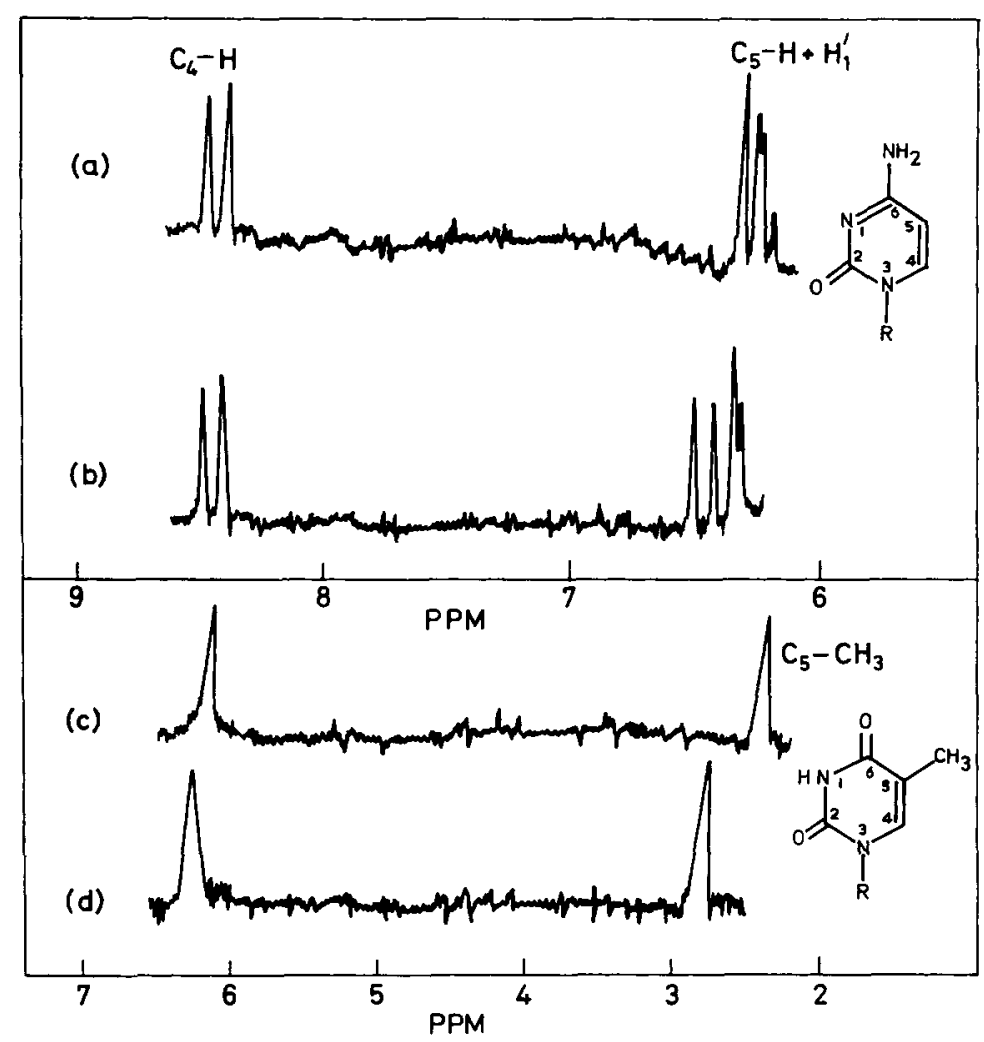

Fig. 5. ${ }^{1} \mathrm{H} \mathrm{nmr}$ spectra of nucleosides, $\mathrm{Au}(\mathrm{III})$-nucleoside, and $\mathrm{Au}$ (III)-nucleotide complexes in $\mathrm{D}_{2} \mathrm{O}$ using sodium 2,2,dimethyl-2-silapentane-5-sulfonate as internal standard. (a) $\mathrm{Cy}$ tidine; (b) Au(III)-cytidine ( $r=0.5$ ); (c) thymidine (at pH=8); (d) Au(III)-thymidine ( $r=$ $1, \mathrm{pH}=8$ ).

findings, along with the ir data, led us to conclude that $\mathrm{N}_{1}$ in cytidine is the metal binding site like $\mathrm{Cu}(\mathrm{II}){ }^{30}$

Some authors have found that uridine or thymidine do not bind to $\mathrm{Zn}$ (II), $\mathrm{Hg}$ (II), $\mathrm{Cu}$ (II), or $\mathrm{Pt}$ (II). ${ }^{27,29,30}$ In the solution of the $\mathrm{Au}$ (III)-thymidine 1:1 stoichiometric mixture at $\mathrm{pH} 8$, we observed a downfield shift of the thymidine $\mathrm{CH}_{3}$ peak. This was not apparent at $\mathrm{pH} 6.5$ of the same solution (cf. Fig. 5). This fact and visible spectral changes show that there is some interaction between $\mathrm{Au}(\mathrm{III})$ and thymidine, the exact nature of which cannot be concluded. But the 1-methyl thymidine and Au(III) mixture 
did not show any change in the nmr spectra at any $\mathrm{pH}$, indicating that $\mathrm{N}_{1}$ of thymidine may be a possible site of chelation.

\section{The Interaction of $\mathrm{Au}(\mathrm{III})$ with Dimethyl Phosphate}

Figure 6 shows the change observed in the change-transfer band of $\mathrm{AuCl}_{4}^{-}$ when mixed with dimethyl phosphate anion. Below $\mathrm{pH} 5$, this change was

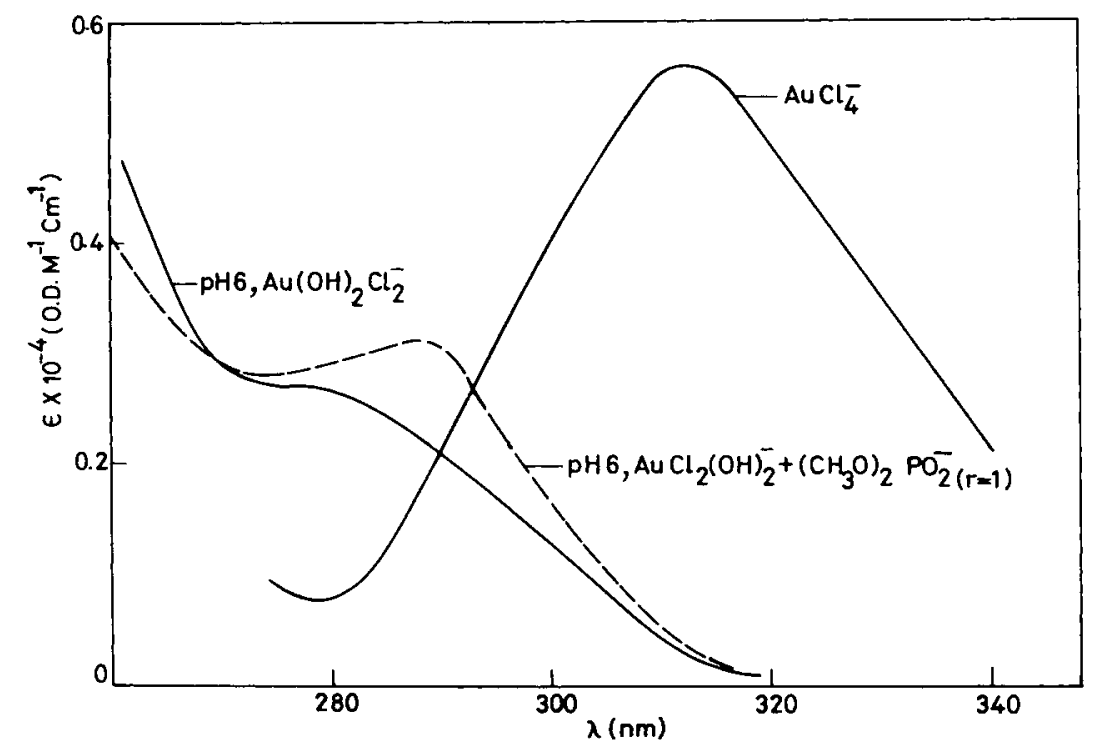

Fig. 6. Change in charge transfer band of $\mathrm{AuCl}_{4}^{-}$with $\mathrm{pH}$ of the medium and in presence of dimethyl phosphate.

not observable. This is presumably because of the fact that around $\mathrm{pH}$ $6 \mathrm{AuCl}_{4}^{-}$exists as $\mathrm{AuCl}_{2}(\mathrm{OH})_{2}^{-}$, which when ionized to $\mathrm{AuCl}_{2}^{+}$facilitates the reaction of two oppositely charged species, such as $\mathrm{AuCl}_{2}^{+}$with $\left(\mathrm{CH}_{3} \mathrm{O}\right)_{2} \mathrm{PO}_{2}^{-}$. In fact, a drastic increase in $\mathrm{pH}$ in the solution was noticed when dimethyl phosphate was added to $\mathrm{Au}(\mathrm{OH})_{2} \mathrm{Cl}_{2}^{-}$.

Further proof of the interaction came from ir and ${ }^{1} \mathrm{H}$ nmr studies. Infrared spectra of the $\mathrm{Au}(\mathrm{III})$-dimethyl phosphate were taken in the solid phase, which was isolated by reacting the $\mathrm{Au}$ (III) ion with barium salt of dimethyl phosphate. Figure 7 shows the perturbation of the $1250 \mathrm{~cm}^{-1}$ band assigned to $\mathrm{P}=0$ of dimethyl phosphate. ${ }^{31}$ The change in the $\mathrm{P}=\mathrm{O}$ band indicates a coordination through phosphoryl oxygen.

The change in ${ }^{1} \mathrm{H} \mathrm{nmr} \mathrm{spectra} \mathrm{was} \mathrm{found} \mathrm{to} \mathrm{be} \mathrm{quite} \mathrm{interesting} \mathrm{(Fig.} \mathrm{7).}$ Dimethyl phosphoric acid shows two doublets with an integration ratio 1:2 and P-C-H coupling constant for both cases was $10 \mathrm{~Hz}$. In the $\mathrm{Au}(\mathrm{III})$ complex of dimethyl phosphate, only one doublet results with the same $J$ value. 


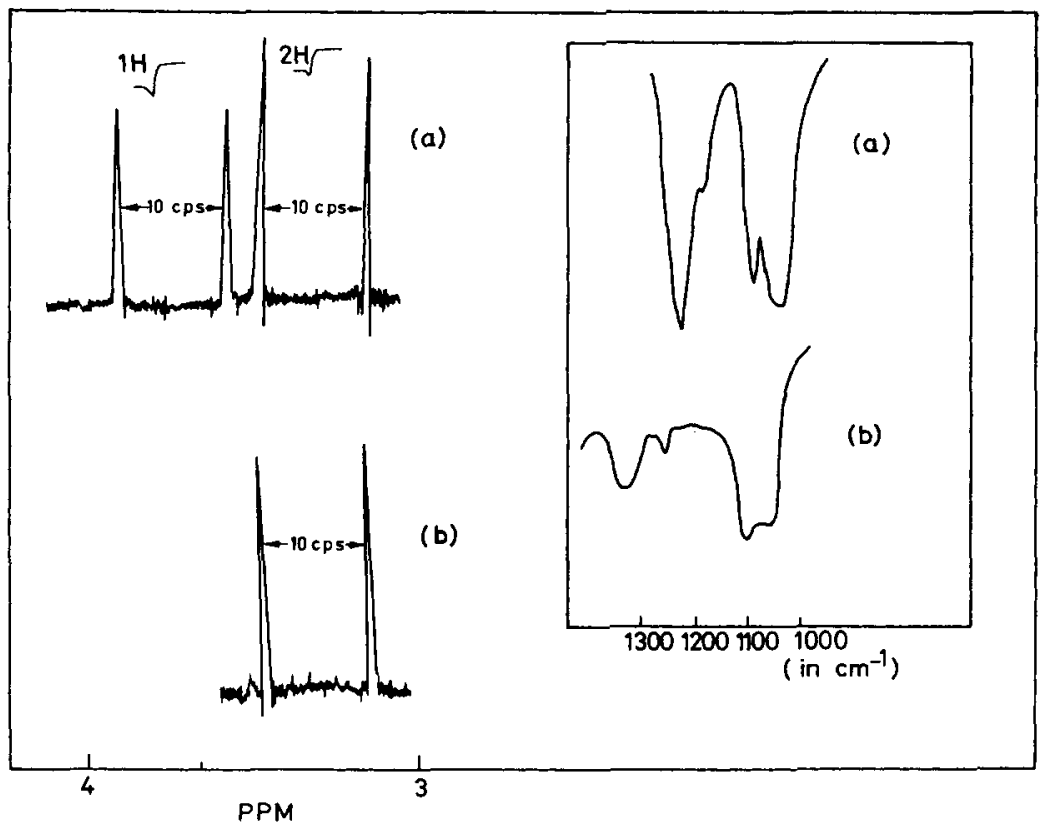

Fig. 7. ${ }^{1} \mathrm{H}$ nmr spectra of (a) dimethyl phosphoric acid, (b) (1:1) dimethyl phosphoric acid- $\mathrm{Au}(\mathrm{Cl})_{2}(\mathrm{OH})_{2}^{-}$at $\mathrm{pH} 6$ in $\mathrm{D}_{2} \mathrm{O}$ using sodium 2,2, dimethyl-2-silapentane-5-sulfonate as an internal standard. Inset shows the change ir spectra of (a) Ba-Salt of dimethyl phosphate and (b) Au complex of $\mathrm{Ba}$-Salt of dimethyl phosphate in dry $\mathrm{KBr}$ pellet.

Dimethyl phosphoric acid has $\mathrm{C}_{3 v}$ symmetry with the structure

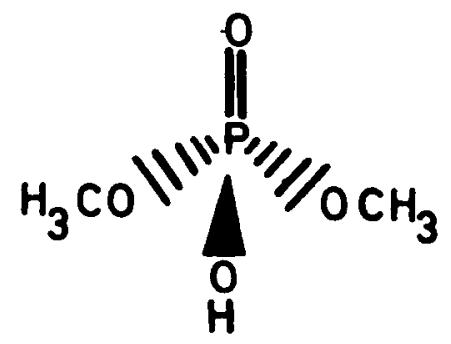

In anionic form the symmetry changes to $\mathrm{C}_{2 v}$ :

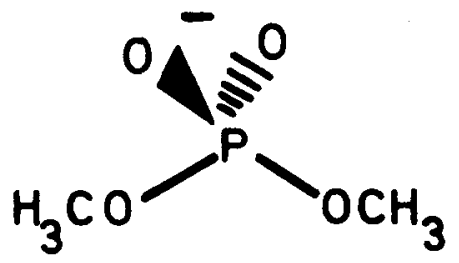

The geometry of dimethyl phosphoric acid induces the restricted rotation around the $\mathrm{O}-\mathrm{CH}_{3}$ bond due to $\mathrm{P}=\mathrm{O}$, as a result of which one hydrogen of each $\mathrm{CH}_{3}$ group is more deshielded than the other two hydrogens, causing two doublets. In the $\mathrm{Au}(\mathrm{III})$ complex the symmetry changes $\left(\mathrm{C}_{2 v}\right)$, due 
to the square planar geometry of the $\mathrm{Au}(\mathrm{III})$ complex, two $\mathrm{CH}_{3}$ groups were symmetrical, resulting in only one doublet.

\section{CONCLUSION}

From the above results the following general conclusions can be drawn:

1. The shoulder in the visible region could not be detected with the pyrimidine nucleoside/(nucleotide). This indicates that $\mathrm{Au}$ (III) forms stronger complexes with the purine nucleosides and nucleotides than with the pyrimidine nucleosides and nucleotides. Though the base free phosphates can interact with $\mathrm{Au}(\mathrm{III})$, the interaction is not as strong as the nitrogen-containing ligands.

2. A nucleotide always acts as a bidentate ligand through ring nitrogen and phosphate. Nucleosides act as a monodentate ligand except for $\mathrm{Au}(\mathrm{III})$-guanosine in 1:1 ratio.

Spectroscopic studies with the Au(III) complexes of thymidine and methyl derivatives of nucleosides could not be performed in detail as these complexes are not stable in $\mathrm{Me}_{2} \mathrm{SO}$. This led us to study the kinetics of solvolysis and halide substitution to these complexes (results of which will be published elsewhere). The substitution was found to take place in a stepwise manner and follows the two-term rate law observed for $\mathrm{d}^{8}$ square planar systems. ${ }^{32}$ From the $\mathrm{pK}_{\mathrm{a}}$ dependence of the rate constants, it was possible to identify the sites of coordination. These data are in good agreement with the results presented here.

\section{References}

1. Izat, R. K., Christensen, J. J. \& Rytting, J. H. (1971) Chem. Rev. 71, 439-481.

2. Eichhorn, G. L. (1973) Inorganic Biochemistry, Elsevier, New York, Vol. 2, pp. 1191-1209.

3. Daune, M. (1974) Metal Ions in Biological Systems, Dekkar, New York, Sigel, H., Ed., Vol. 3, pp. 1-43.

4. Moudrianakis, E. N. \& Beer, M. (1962) Proc. Natl. Acad. Sci. U.S. 48, 409-416.

5. Highton, P. J. \& Beer, M. (1968) J. Roy. Microsc. Soc. 88, 23-26.

6. Rosenberg, B. (1973) Naturwissenchaften 60, 399-406.

7. Aggarwal, S. K., Wagner, R. W., Meallister, P. K. \& Roserberg, B. (1975) Proc. Natl. Acad. Sci. U.S. 72, 928-932.

8. Cleare, M. J. (1974) Coord. Chem. Rev. 12, 349-405.

9. Gibson, D. W., Beer, M. \& Barrnett, R. J. (1971) Biochemistry 10, 3669-3679.

10. Pillai, C. K. S. \& Nandi, U.S. (1973) Biopolymers 12, 1431-1435.

11. Tsubeoi, M., Kuriyagawa, F., Matsuo, K. \& Kyogoku, Y. (1967) Bull. Chem. Soc. Jpn. 40, 1813-1818.

12. Marynick, D. S. \& Schaefer, H. F., III (1975) Proc. Natl. Acad. Sci. U.S. 72, 37943798.

13. Jones, J. W. \& Robins, R. K. (1963) J. Am. Chem. Soc. 85, 193-201.

14. Brookes, P. \& Lawley, P. D. (1962) J. Chem. Soc. 1348-1351.

15. Haines, J. A., Reese, C. B. \& Todd, L. (1964) J. Chem. Soc. 1406-1412. 
16. Cattalini, L. \& Tobe, M. L. (1966) Inorg. Chem. 5, 1145-1150.

17. Gangopadhya, A. K. \& Chakrabarty, A. (1961) J. Chem. Phys. 35, 2206-2209.

18. Voet, D., Gratzes, W. B., Cox, R. A. \& Doty, P. (1961) Biopolymers 1, 193-208.

19. Mason, W. R. \& Gray, H. B. (1968) Inorg. Chem. 7, 55-58.

20. Tsuboi, M. \& Kyogoku, Y. (1968) Synthetic Procedure in Nucleic Acid Chemistry,

Zorbach, W. W. \& Tipson, R. S., Eds., Interscience, New York, Vol. 2, pp. 215-265.

21. Hartman, K. A., Jr. (1967) Biophys. Biochem. Acta 138, 192-195.

22. Tsuboi, M., Takahasi, S. \& Harada, I. (1973) Physico Chemical Properties of Nucleic Acids, Duchesne, J., Ed., Academic, New York, Vol. 2, pp. 92-146.

23. Jardetzky, C. D. \& Jardetzky, O. (1960) J. Am. Chem. Soc. 82, 222-229.

24. Bullock, J. J. \& Jardetzky, O. (1964) J. Org. Chem. 29, 1988-1990.

25. Schweizer, M. P., Chan, Si \& Ts'o, P. O. P. (1965) J. Am. Chem. Soc. 87, 5241-5247.

26. Kong, P. C. \& Theophanides, T. (1974) Inorg. Chem. 13, 1167-1170.

27. Kan, L. S. \& Li, N. C. (1970) J. Am. Chem. Soc. 92, 4823-4827.

28. Shimokawa, S., Fukui, H., Shoma, J. \& Hotta, K. (1973) J. Am. Chem. Soc. 95, 1777-1782.

29. Kong, P. C. \& Theophanides, T. (1974) Inorg. Chem. 13, 1981-1985.

30. Eichhorn, G. L., Clark, P. \& Becker, E. D. (1966) Biochemistry 5, 245-253.

31. Brown, E. B. \& Peticolas, W. L. (1975) Biopolymers 14, 1259-1271.

32. Edwards, J. O., Ed. (1970) Progress in Inorganic Chemistry, Interscience Publishers, New York, Vol. 13, pp. 263-327.

Received February 26, 1976

Accepted October 26, 1976 